\title{
PRANA DAN GAYA HIDUP : UPAYA MENINGKATKAN ENERGI VITAL TUBUH
}

\author{
Oleh: \\ Putu Reny Rahmawati \\ Akademisi tinggal di Klungkung \\ Email: \\ Renyrahmawati41@gmail.com
}

\begin{abstract}
Abstrak:
Pranayama merupakan pengendalian nafas dalam yoga. Pranayama mengendalikan prana (energi vital) dalam tubuh, dengan penarikan dan penghembusan nafas yang dikontrol serta dikendalikan mengakibatkanenergi vital yang semakin meningkat sehingga mampumempengaruhi pikiran semakin tenang maupun tubuh semakin sehat. Dengan melakukan praktik Pranayama dan menjadikannya sebagai gaya hidup di masa kini atau era modern ini, dapat membuat seseorang semakin lebih sehat dan memiliki pikiran yang jauh lebih baik. Beberapa praktek pranayama yang bisa dilakukan yaitu sepert : Suryabedha Pranayama, Sitali Pranayama, Sitkari Pranayama, Ujayi Pranayama, Bashrika Pranayama, Kapalabhati Pranayama dan masih banyak lagi Pranayama dengan manfaat yang berbeda - beda sesuai kebutuhan praktisi yoga dan tetap pada peningkatan energi vital dalam tubuh

Pranayama is breath control in yoga. Pranayama controls prana (vital energy) in the body, with the controlled and controlled withdrawal and exhalation resulting in increased vital energy so that it can influence the mind more calmly and the body more healthy. By doing the practice of Pranayama and making it a lifestyle in the present or the modern era, it can make a person more healthy and have a much better mind. Some pranayama practices that can be done are: Suryabedha Pranayama, Sitali Pranayama, Sitkari Pranayama, Ujayi Pranayama, Bashrika Pranayama, Kapalabhati Pranayama and many more Pranayama with different benefits according to the needs of yoga practitioners and remain in increasing vital energy in the body
\end{abstract}

Kata kunci: Bahung Tringan, Dwi Tunggal, Siwa-Buddha

\section{PENDAHULUAN}

\section{KONSEP PRANA}

Dalam perkembangan yoga di India, prānāyāma menempati posisi vital dalam yoga disamping asana.Setiap brahmacari dan grhastha harus melakukannya sebanyak tiga kali setiap pagi, siang dan malam, serta setiap kali melakukan puja dan tri sandhyā.Prānāyāma diharapkan dilakukan dalam setiap aktivitas baik keagamaan maupun dalam aktivitas sehari-hari. Disini saya ingin membicarakan sebuah cara kosentrasi yang sangat sulit dimana dalam istilah Hindu dikenal dengan sebutan 'Satāvadhāni' atau seorang kosentrator, berupa test memori verbal dari si pelaku, test mengenai daya perkiraan mentalnya, selain itu beberapa orang yang lain berusaha untuk menguji keterampilan artistiknya tanpa memberikan waktu untuk memikirkan dan menjawab pertanyaan yang diajukan padanya sebelumnya. Dengan membuat suatu pertanyaan sesuai dengan alurnya dan aturannya. Pelaksana akan memulai dengan jawabannya. Pada umumnya akan dilakukan sebanyak tiga putaran atau lebih, dimana pada tiap-tiap putaran akan diberikan porsi pada masing jawaban di setiap pertanyaan. Jika pertanyaan 
tersebut berkaitan dengan matematika yang memerlukan solusi maka akan diberikan jawaban bersama dengan masalahnya yang nantinya dipecahkan secara mental. (Sivananda dalam Surya Wijaya, 2007 : iv-v)

Dengan pranayama setiap hari maka ingatan yang sesulit apapun akan dapat diperoleh. Prāna dapat dijelaskan sebagai kekuatan yang sangat penting dan vital yang meliputi seluruh kosmos baik itu pada bidang fisik dalam wujudnya sebagai gerak atau kegiatan, dan pada bidang mental dalam wujudnya sebagai pikiran dan oleh sebab itu kata Prānāyāma mempunyai arti sebuah penahanan energi vital yang dalam prakteknya merupakan suatu pengendalian energy vital yang merangsang syaraf seseorang, dan yang menggerakkan otototot serta yang menyebabkan seseorang dapat merasakan dunia external dan memikirkan bathinnya. Energi ini vis viva (daya hidup) yang merupakan sifat dasar dari organisme binatang. Pengendalian terhadap kekuatan ini yang menjadi tujuan para yogi lewat prānāyāma.Bagi siapa saja yang dapat menaklukkannya maka ia tidak hanya sebagai penakluk esistensi dirinya tetapi juga akan menjadi penkluk segenap dunia, hal ini disebabkan karena prāna adalah inti dari semua kekuatan dan kehidupan kosmis yang dalam kehadirannya saat ini merupakan pringsif halus yang meliputi seluruh alam semesta adalah badan bagi para yogi. Materi yang menutupi badannya dengan yang menutupi alam semesta adalah sama. Kekuatan yang menggerakkannya pun sama, dan oleh sebab itu dengan menaklukan badan berarti telah menaklukan alam semesta. Menurut filsafat Hindu terdapat dua subtansi yang menyusun seluruh alam semesta yaitu $\bar{a} k \bar{a} s ́ a$ dan prāna atau energi, yang kedua menurut para ilmuan modern berkaitan dengan materi dan daya. Apapun didunia ini memiliki suatu eksistensi material yang berasal dari subtansi halus yang disebut dengan ' $\bar{a} k \bar{a} s a^{a}$ ' yang meresapi segalanya da nada dimana-mana. Seluruh alam yang tersusun dari unsur gas, cair dan padat yang merupakan hasil dari ' $\bar{a} k \bar{a} s a^{a}$ ' yang tidak kelihatan dan halus, yang pada setiap akhir dari siklus kembali ke titik awalnya. Semua kekuatan yang diketahui manusia seperti gravitasi, cahaya, panas, magnet dan listrik juga merupakan bagian dari prāna kosmis yang berasal dari prāna dan nantinya juga akan kembali ke dalam wujud prāna. Tidak ada suatu yang baru dapat terjadi selain berkat adanya dua unsur ini yang menjadi salah satu penyusunnya. (Sivananda dalam Surya Wijaya, 2007 : v-vi)

Seseorang yang memahami prāna berarti ia telah mampu memahami inti kehidupan dan aktivitas kosmos. Siapapun yang mampu menaklukan dan mengandalikan hakekat ini, maka ia tidak akan memahami badan dan pikirannya sendiri tetapi ia juga dapat memahami badan dan pikirannya sendiri tetapi ia juga dapat memahami badan dan pikiran orang lain di alam semesta ini. Prānāyāma merupakan suatu cara bagi yogi yang ingin mencoba menyadari badan yang kecil sebagai bagian dari keseluruhan kehidupan kosmis, dan memperoleh kekuatan dari alam semesta. (Sivananda dalam Surya Wijaya, 2007 : vi-vii)

Nafas adalah bentuk luar dari prāna, yang bersifat sthūla, atau kasar dan yang bersifat sūksma atau halus.Didalam prānāyāma dikenal adanya latihan menghirup nafas atau Svāsa, kumbhaka atau menahan, dan menarik nafas atau praśvāna, dengan latihan mengendalikan nafas, seseorang mampu mengendalikan prāna halus yang berada di dalam.Pengendalian pikiran dapat dilakukan lewat pengontrolan prāna, karena pikiran tak dapat bekerja tanpa bantuan prāna.Karena prāna yang menghasilkan pikiran dalam otak, dan menjadi penggerak pikiran. Sūksmaprāna atau prāna fisik inilah yang mempunyai hubungan erat dengan pikiran.Prānāyāma menggunakan nafas untuk mempengaruhi aliran prāna pada nādī (saluran prāna) dari prānāyāmakośa (kumpulan kekuatan hidup). Melalui proses ini akan membersihkan $n \bar{a} d \bar{\imath}$ dan menyebabkan keseimbangan fisik dan mental, prāna akan dapat dikendalikan dan 
akhirnya akan menguwasai pikiran.(Sivananda dalam Surya Wijaya, 2007 : 1)

Dalam sruti ada sebuah pernyataan penting yaitu "Yang mengetahui prāna juga akan mengetahui Veda”. Dalam Vedanta Sutra ditemukan bahwa, "Dengan alas an yang sama, nafas adalah Brahman". Prāna merupakanjumlah total dari daya dan kekuatan terpendam yang tersembunyi pada manusia dan yang terdapat dimana-mana, dan yang bermanifestasi pada panas, cahaya, listrik dan magnet. (Sivananda dalam Surya Wijaya, 2007 : 2)

$\bar{A}$ tman adalah semua tenaga dan prāna yang memancarkan semua kekuatan fisik dan mental dapat dikatagorikan sebagai 'prāna'.Prāna merupakan dasar kekuatan pada setiap keberadaan makhluk hidup, dari yang tertinggi sampai pada yang paling rendah.Apapun yang bergerak atau bekerja ataupun yang mempunyai nyawa, adalah bentuk dan wujud dari prāna.Ākasa merupakan salah satu wujud prāna.Prāna itu dihubungkan dengan pikiran dan elalui pikiran menuju kehendak kemudian melalui kehendak menuju roh individual, dan melalui ini ia akan mencapai suatu keberadaan yang tertinggi. Rahasia penaklukan prāna terletak pada pengendalian gelombang kecil prāna pada pikiran.Para resi yang menguwasai metode ini tidak pernah mempunyai rasa takut pada apapun karena telah menguwasai berbagai kekuatan alam semesta.Kekuatan prāna aka membuat orang lebih sukses dalam kehidupan, tetapi ada juga yang menggunakannya untuk hal yang lebih rendah. Sistim kerja prāna terlihat pada sistim kerja urat alteri dalam memompa darah pada saat pernafasan.Prāna juga berfungsi pada sistim pencernaan, pembuangan.Dan berfungsi pelaksanaan kegiatan sehari-hari, seperti berjalan, bermain, berbicara. Penghubung antara badan astral dan badan fisik disebut prāna, yang berbentuk seperti mata rantai atau benang tipis, jika benang tipis ini terputus maka badan astral akan terpisah dari badan fisik dan kematian akan datang. (Sivananda dalam Surya Wijaya, 2007 : 2-3)

Prāna bergerak dan bereaksi terhadap ākaśa jika terjadi vibrasi dan inimenyebabkanterciptanya berbagai bentuk.Penggabungan antara prāna dan $\bar{a} k a s ́ a$ menghasilkas makrokosmos (brahmānda) dan mikrokosmos (pindānda).Semua yang ada di alam semesta ini digerakkan oleh prāna atau merupakan hasil dari prāna.Semua gerakan badan dapat dikendalikan melalui pengendalian nafas. Seseorang dapat dengan mudah mengendalikan dan mengembangkan tubuh, jiwa dan pikiran jika anda telah dapat mengendalikan nafas atau prāna. Dengan dikendalikannya prāna maka akan tercipta keselarasan kehidupan individual dengan kehidupan kosmis. Nafas adalah merupakan suatu daya vitalisasi yang dapat memperbaharui dan berguna untuk mengembangkan diri, serta dapat menyembuhkan segala macam penyakit jika digunakan dibawah pengendalian pikiran. (Sivananda dalam Surya Wijaya, 2007 : 3)

Dalam buku Light On Pranayama oleh BKS Iyengar juga disebutkan bahwa 'Prana' berarti nafas, respirasi, kehidupan, daya hidup, energi atau kekuatan. 'Ayama' berarti perpanjangan, perluasan, Panjang, pengaturan, mengendalikan atau menguasai. Jadi pranayama adalah perpanjangan nafas dan pengendaliannya. Tubuh manusia memiliki 5 lapisan tubuh sebagai wahana roh dalam diri, 5 lapisan tubuh ini disebut Panca Maya Kosa dalam ajaran Agama Hindu, hal ini juga berhubungan pada prana dalam diri.

Menurut kedokteran Timur (Cina) seorang dokter dianggap hebat bukan kalau ia mampu mengobati sakit.melainkan kalau ia mampu mencegah sakit. Konon, dokter- dokter istana kekaisaran akan mendapat banyak uang kalau keluarga kerajaan tidak sakit. Sebaliknya kalau keluarga lerajaan pada sakit, sang dokter malahan mendapat banyak teguran. Oleh karena itu para dokter Cina selalu berusaha mencegah datangnya sakit dengan mengajarkan pada keluarga kerajaan tip-tip supaya sehat. Hal penting untuk menjaga 
kesehatan adalah dengan melakukan usaha- usaha preventif. Pepatah Cina mengatakan bahwa mengobati dikala sakit adalah sangat berat karena ibarat kita menggali sumur pada saat kita kehausan. Cara yang paling utama adalah tentu saja dengan meningkatkan kekebalan tubuh sendiri. Bila sistim kekebalan tubuh cukup baik, maka segala penyakit yang masuk ke tubuh akan diusir oleh tubuh sendiri. Seperti dikatakan oleh Dr. Deepak Chopra MD, penulis best seller Quantum Healing, tubuh kita sudah mempunyai sistim informasi yang sangat canggih yang secara otomatis bekerja. Bila keseimbangan tubuh terjaga, ia akan meproduksi sendiri obat-obatannya sendiri yang lebih canggih dan efektif

Energi vital sering disebut sebagai qi atauchi (Cina), ki (Jepang) atau prana (India). Pendekatan kesehatan timur, memandang chi sebagai hal yang sangat penting bagi kesehatan seseorang. Kehidupan ada karena ada chi. Kalau tidak ada kehidupan seorang manusia akan kehilangan chi. Manifestasi chi ini bisa dilihat pada layar EKG (electrokardiographi ) yang biasanya dipasang pada tubuh pasien saat kondisi kritis. Grafik gelombang listrik yang mendatar pada EKG menadakan bahwa sang pasien telah kehilangan chi yang berarti sudah mati. Di kedokteran Timur chi sangat menentukan sekali bagi kesehatan seseorang. Bahkan pengobatan Cina mendasarkan terapinya pada jalur aliran chi yang ada di tubuh. Pada tubuh manusia terdapat 12 aliran chi (meridian) organ dalam dan dua aliran yang mengalir di tengah tubuh bagian depan . (mwridian ren) dan mengalir di bagian tengah tubuh bagian belakang (meridan Du). Ketidaklancaran aliran ini dapat mengabitkan ketidakseimbangan seseorang dan berati sakit.

Faktor chi ini sama pentingnya dengan pernapasan, sistem pencernaan dan sistem motoris dan limfe yang dikenal dunia medis barat. Chi dalam istilah Cina atau prana dalam bahasa India adalah energi hidup. Di dunia ini banyak sumber chi yaitu makanan, olah raga, tingkah laku dan pernapasan.
Ada keyakian pada jaman kuno bahwa mutu hidup seseorang sangat ditentukan oleh kualitas chinya . Chi yang seimbang akan membuat tubuh sehat dan bugarr. Sebaliknya chi yang kacau dan tidak seimbang dapat menyebabkan sakit. Sama halnya dengan mobil, chi dapat diibaratkan dengan sistem kelistrikan mobil itu.

Analog dengan mobil, maka tubuh manusia juga perlu dilakukan tune-up seperti mbil. Caranya adalah dengan melakukan tune up energi (chi). Caranya ada bermacam- mcam. Bisa menggunakan tusuk jarum, pemijatan titik titik akupunktur, pengerokan, moksibasi (penyembuhan dengan menggunakan moksa yang berasal dari daun ai yang dibakar untuk memanaskan jalur- jalur energi yang ada di tubuh (meridian), pengekopan atau menggunakan gerakan gerakan. Olahraga taichi, meditasi dengan reiki, pada dasarnya bertujuan untuk menyeimbangkan chi yang ada di tubuh. Salah satu teknik penyelarasan chi yang sedang populer saat ini adalah konsep totok energi. Di negara Barat ilmu ini sering disebut sebagai energy psychology, tought field theory, atau emotional freedom technique. Berbagai seminar dan pelatihan yang digelar tentang energi ini selalu mendapat sambutan yang luar biasa dari publik karena kemudahan dan kepraktisannya. Kita tidak perlu belajar bertahun- tahun untuk menguasai ilmu ini. Pelatihan sehari atau dua hari cukup untuk menjadikan mereka mampu mengobati masalah fisik dan emosi mereka secara mandiri. (https://gmpjconsulting.com/2014/08/05/ menyeimbangkan-energi-tubuh-cara-mudah-danmurah-untuk-sehat-dan-hidup-lebih-produktif/)

Gaya Hidup adalah bagian dari kebutuhan sekunder manusia yang bisa berubah bergantung zaman atau keinginan seseorang untuk mengubah gaya hidupnya. Istilah gaya hidup pada awalnya dibuat oleh psikolog Austria, Alfred Adler, pada tahun 1929. Pengertiannya yang lebih luas, sebagaimana dipahami pada hari ini, mulai digunakan sejak 1961. Gaya hidup bisa dilihat dari cara berpakaian, kebiasaan, dan lain-lain. Gaya 
hidup bisa dinilai relatif tergantung penilaian dari orang lain. Gaya hidup juga bisa dijadikan contoh dan juga bisa dijadikan hal tabu. Contoh gaya hidup baik: makan dan istirahat secara teratur, makan makanan 4 sehat 5 sempurna, dan lain-lain. Contoh gaya hidup tidak baik: berbicara tidak sepatutnya, makan sembarangan, dan lain-lain. (https://id.wikipedia.org/wiki/Gaya_hidup)

Gaya hidup masa kini yaitu pada era modern terlihat dari beberapa hal, diantaranya yaitu mobilitas yang tinggi, hidup serba instan, gaya hidup yang berpacu pada teknologi informasi dan komunikasi dan lain sebagainya. Dampak yang disebabkan dari gaya hidup masa kinipun sangat beragam dan menjadikan kesehatan, mental maupun kehidupan sosial masyarakat sangat berbeda bahkan menuju kea rah negatif. Dilihat dari segi kesehatan pada masa kini, pola makan yang ingin seinstan mungkin membuat tingkat kesehatan masyarakat menurun, bahkan sayuran dan buah-buahan yang dinilai sangat baik untuk kesehatan karena kandungan vitamin serta seratnya begitu tinggipun tidaklah semuanya masih benarbenar baik dikonsumsi karena banyak petani yang memberikan pestisida atau obat kimia kepada sayuran atau buah-buahan tersebut. Sehingga pada era modern ini sangatlah penting berhati hati untuk memilih makanan yang sehat, jika tidak maka berbagai penyakit akan dating menyerang tubuh. Kesibukan merupakan salah satu dari gaya hidup masa kini, banyak masyarakat lebih mementingkan atau mengejar uang untuk modal melangsungkan hidupnya, maka tidak salah jika mobilitas diera modern ini semakin tinggi. Penyebab yang paling terlihat yaitu adalah polusi udara dimana mana, bahkan pedesaanpun kini tidak seutuhnya asri dan dan memiliki udara segar. Hal lain yang juga merupakan dampak yaitu adalah pola piki masyarakat yang semakin sempit bahkan menyebabkan stress berlebih. Pada masa kini penyakit banyak ditimbulkan dari tekanan pikiran.
Masalah Prana dan Gaya Hidup Masa Kini terlihat dari gaya hidup yang semakin tidak baik dan membuat tubuh semakin tidak sehat. Akibatnya prana dalam diri akan semakin meredup. Hal ini dapat dilihat dari Panca Maya Kosa. Dalam konteks manusia (Bhuwana alit) Prakerti adalah lapisan-lapisan badan yang membungkus kesadaran murni Purusha atau Roh Dimana perpaduan keduanya membentuk dua jenis wahana atau badan, yaitu badan fisik dan badan pikiran. Badan fisik mudah kita ketahui. Tapi badan-badan pikiran kita berada pada alam yang lebih halus, tidak bisa kita lihat dan rasakan dengan indriya badan fisik kita, sehingga kita tidak memperhatikannya. Sebagaimana termuat dalam Taittriya Upanishad dan buku-buku suci Hindu lainnya Roh kesadaran murni dibungkus oleh lima lapisan badan yang terbentuk dari lima jenis energi-materi dan energi-kesadaran, yang disebut dengan Panca Maya Kosha. Lima lapisan badan ini sebagai wahana Roh dalam siklus Reinkarnasi, yaitu:

1. Annamaya Kosha - Lapisan badan yang tersusun dari energi sari-sari makanan. Terdiri dari dua sub lapisan yaitu sthula sarira dan linga sarira.

2 Pranamaya Kosha - Lapisan badan yang tersusun dari energi prana, yaitu samudera besar energi pembentuk kehidupan yang ada di semua penjuru alam Semesta. Lapisan ini terkait jejaring energy prana, terdapat hal dasar yg perlu dijelaskan terlebih dahulu yg terdiri dari: Nadi, Cakra, Granthi dan Kundalini.

3. Manomaya Kosha - Lapisan badan yang tersusun dari energi pikiran biasa. Terdiri dari dua sub lapisan, yaitu "Sukhma Sarira dan Karana Sarira".

4. Vijnanamaya Kosha - Lapisan badan yang tersusun dari energi pikiran yang halus dan sadar.

5. Anandamaya Kosha - lapisan badan yang tersusun dari energi alam semesta yang transenden

(http://www.pasramanganesha.sch.id/2016/04/ panca-maya-kosha-lima-lapisan-badan.html) 
Lapisan ini akan melemah ketika lapisan luar terganggu, Hanya lapisan Annamaya Kosha saja atau Pranamaya kosa mengalami gangguan atau semakin meredup maka lapisan selanjutnya akan melemah pula. Melemahnya lapisan tersebut diakibatkan oleh tubuh yang tidak sehat, pikiran yang tidak kuat maupun pola hidup yang tidak baik. Pada lapisan Annamaya Kosha prana dapat ditingkatkan dengan cara melakukan aktivitas fisik seperti berolahraga, yoga maupun kegiatan olah tubuh lainnya. Sedangkan pada Pranamaya Kosha , prana dapat ditingkatkan dengan melatih pranayama untuk meningkatkan energi pada lapisan tersebut.

Kini pada era modern pola hidup maupun kegiatan hidup lebih banyak tidak sehat atau tidak baik, hal tersebut mempengaruhi prana dalam tubuh. Ketika tubuh tidak sehat secara mental, fisik, spitual maupun sosial maka prana dalam tubuh juga akan terganggu. Melalui olah prana atau Pranayama maka energi vital dalam tubuh akan semakin meningkat. Ini merupakan solusi yang baik bagi masyarakat yang hidup di masa kini. Dengan mempraktekannya secara rutin dan bertahap maka energi vital akan tetap terjaga, begitupula tubuh akan tetap terjaga kesehatannya bahkan pikiranpun akan tetap terkontrol. Karena dengan mengatur prana melalui nafas, pikiran akan lebih mudah terkontrol sehingga perilaku dalam diri juga akan sesuai dengan pikiran yang baikpula.

\section{BAB II PEMBAHASAN}

Mengatur gaya hidup dengan baik akan mempengaruhi prana dalam tubuh. Tetap berada pada era modern tanpa kehilangan prana merupakan hal yang tidak sulit untuk dilakukan, dengan menjaga pola makan yang baik, menjaga pikiran tetap sehat dengan mengontrolnya ataupun melakukan beberapa usaha fisik maupun spiritual, serta melatih mental dengan memperbaiki diri dengan lingkungan sosial di sekitar.
Upaya atau cara untuk meningkatkan energi vital dalam diri yaitu dapat dilakukan dengan membiasakan diri mengkonsumsi makanan yang bersifat sattvika agar tubuh tetap terjaga kesehatannya. Melakukan beberapa meditasi untuk menenangkan pikiran yang sering mengalami tekanan di era modern ini, dan hal yang paling penting serta mempengaruhi prana dalam tubuh yaitu melatih diri dengan melakukan pranayama atau olah nafas. Beberapa definisi pranayama menurut beberapa sumber yaitu :

\section{Tasmin sati svasaprasvasayor-} gativicchedah pranayamah

"Pengaturan nafas atau pengendalian terhadap prana adalah penghentian dari penghirupan dan penghembusan nafas yang terlebih dahulu dilakukan dengan sikap duduk yang tegak"

(Patanjali Yoga Sutra, Bab II - 49)

2. Tasmin sati svasaprasvasayorgativicchedah pranayamah

"Setelah menguasai asana, gati atau kecepatan nafas yang masuk dan keluar dapat dikurangi, dikendalikan. Dengan demikian, prana atau aliran kehidupan ikut terkendali. (Inilah yang disebut Pranayama)

(Patanjali Yoga Sutra, Bab II - 49)

3. Pranayama diartikan sebagai suatu rangkaian tekhnik yang merangsang dan meningkatkan energi yang sangat penting, pada akhirnya menimbulkan pengendalian yang sempurna pada aliran prana tubuh. (Satyananda Sarasvati Svami, 301)

Prana merupakan vyasti, jika seseorang tetap tekun. Hiranyagarbha adalah jumlah total energi kosmis atau prana kosmis yang dikenal sebagai 'telur emas mengambang'. Hiranyagarbha juga disebut samsthi prana. Sebuah batang korek api adalah vyasi. Keseluruhan batang korek api adalah samasti. Energi di dalam tubuh adalah prana. Dengan mengendalikan paru - paru atau gerak pernafasan, kita dapat mengendalikan prana 
yang bergetar didalam. Dengan mengendalikan prana, maka pikiran akan dengan mudah dapat dikendalikan, seperti burung yang diikat dengan tali, atau ibarat burung yang terikat pada sebuah tiang dengan seutas tali setelah terbang kesana kemari, makai a akan berhenti pada tiang tersebut, demikian halnya juga dengan pikiran setelah berkelana kian kemari pada berbagai macam objek sensual, maka ia akan hinggap lagi ditempat peristirahatan selama tidur nyenyak dalam prana (Sivananda dalam Surya Wijaya, 2007 : 41 - 42)

Penguasaan asana dan pengendalian tubuh adalah langkah awal yang penting dalam pengendalian nafas. Dan latihan itu dapat dilanjutkan dengan pranayama. Sikap yang benar diperlukan untuk keberhasilan dalam pranayama. Sikap badan yang enak dan nyaman adalah asna. Sikap badan yang terbaik adalah sikap yang nyaman yang dilakukan dalam jangka waktu lama. Pranayama merupakan pengendalian prana dan daya - daya vital dari badan yang dipraktekan lewat pengaturan nafas. Tujuan pranayama adalah mengendalikan prana. Lewat pranayama arus daya kehidupan atau kekuatan vital didalam akan. Dengan kata lain, pranayama adalah pengendalian yang sempurna terhadap arus kehidupan melalui pengendalian pernafasan. Nafas adalah wujud luar dari prana kasar. Bagi orang - orang awam yang nafasnya tidak teratur kebiasaan yang benar dalam bernafas harus dilaksanakan lewat latihan pranayama yang teratur. Bila seseorang mengendalikan nafas atau prana, pikirannya juga terkendalikan. Mereka yang telah mampu mengendalikan pikirannya juga dapat mengendalikan nafasnya. Bila satu ditunda maka lainnya juga akan tertunda. Bila pikiran dan prana keduanya dikendalikan, maka seseorang akan mendapat pembebasan dari siklus kelahiran dan kematian dan mencapai keabadian. Adahubungan yang era tantara pikiran, prana dan sperma. Bila seseorang mampu mengendalikan energi seminal, pikiran, prana juga akanikut terkendalikan. Mereka yang melatih pranayama akan mempunyai nafsu makan yang baik, penuh keceriaan, sosok yang menawan, ketangkas, berani, antusias, kesehatan yang prima, vitalitas serta konsentrasi pikiran yang baik. Pranayama juga masih cocok untuk orang orang barat. Seorang yogi mengukur jangka waktu kehidupannya tidak berdasarkan jumlah usia tetapi didasarkan atas jumlah nafasnya. Anda dapat menghirup sejumlah energi atau prana tertentu drai udara atmosfir Bersama - sama dengan setiap tarikan nafas yang dilakukannya. Kemampuan vital adalah kemampuan yang diperlihatkan dengan menghirup sejumlah besar udara yang dilakukan setelah mengeluarkan nafas sedalam mungkin. Seseorang melakukan 15 kali bernafas dalam setiap menit, maka jumlah total nafas akan menjadi 21.600 kali perhari. (Sivananda dalam Surya Wijaya, 2007 : 47)

Pranayama dapat dibagi menjadi tiga jenis : adhama, madhayama, dan uttama ( yang rendah, sedang, atau paling tinggi ). Adhama pranayama terdiri dari 12 mantra, madhayama terdiri dari 24 mantra dan uttama menyita waktu 32 mantra. Ini untuk melakukan puraka atau penarikan nafas. Rasio adalah puraka, kumbaka dan recaka adalah $1: 4: 2$. puraka adalah penarikan nafas, kumbhaka adalah penahanan nafas dan recaka adalah penghembusan nafas. Apabila menarik nafas selama 12 mantra, maka harus melakukan kumbhaka selama 48 mantra. Lalu saat untuk melakukan (penghembusan nafas) recaka akan menjadi 24 mantra, hal ini dilakukan untuk melakukan adhama pranayama. Peraturan yang sama akn dipergunakan pada dua variasi lainnya. Berlatihlah adhama pranayama selama 1 bulan kemudian madhyama selama tiga bulan, setalah itu lakukanlah jenis uttama (Sivananda dalam Surya Wijaya, 2007 : 51)

Beberapa pranayama untuk meningkatkan energi vital dalam tubuh yaitu:

1. Surya Bedha Pranayama

Pranayama ini mengaktiThan pinggala nadi sehingga memberikan tenaga yang dinamis 
pada pelakunya untuk dapat melakukan kegiatan fisik yang lebih efesien. Surya bheda dapat dilakukan dengan cara :

Duduklah dengan sikap padmasana atau siddhasana. Tutup mata anda, smabil tangan anda menutup lubang hidung kiri dengan jari manis dan kelingking tangan knan. Kemudian Tarik nafas pelan - pelan tanpa menimbulkan suara semampu yang biasa anda lakukan dengan perasaan yang nyaman melalui lubang hidung kanan. Kemudian tutup lubang hidung kanan dengan ibu jari kanan dan tahan nafas secara mantap dengan menekan dagu ke dada (jalandhara bandha). Tahan nafas sampai keringat mengalir dari ujung kuku dan akar ramb. Anda harus meningkatkan waktu kumbhaka secara berangsur - angsur, karena anda tidak dapat melakukannya hanya dipermukaan saja.

Kemudian hembuskan nafas pelan - pelan tanpa menimbulkan bunyi melalui lubang hidung kiridengan menutup lubang hidung kanan dengan ibu jari. Selama bernafas ucapkan mantra Om secara mental dengan bhava dan makna nya, menahan nafas dan mengeluarkan nafas. Hembuskan nafas setelah menyucikan tengkorak kepala dengan memaksa nafas naik. Pranayama ini harus dilakukan berulang kali untuk membersihkan otak dan menghancurkan cacing usus dan penyakit yang timbul dari kelebihan angin (vayu). Inilah yang dapat melenyapkan empat jenis kejahatan yang disebabkan oleh vayu dan menyembuhkan vata atau rematik. Ia juga akan menyembuhkan rhinitis (radang selaput lendir hidung), chepalalgia (sakit kepala), dan berbagai jenis penyakit syaraf. Cacing yang ditemukan pada rongga sinus dilenyapkan. Pranayama ini akan menghancukan kemerosotan dan kematian, membangkitkan kundalini sakti dan meningkatkan api jasmani. Pranayama ini akan lebih memanaskan tubuh ketika dilakukannya, maka berlatihlah ketika udara atau musim dingin. Lain halnya ketika melakukan Candra Bedha Pranayama yang akan membuat tubuh semakin dingin, mempraktekan pranayama ini pun dianjurkan ketika cuaca sedang panas atau saat musim musim panas, agar keadaan tubuh dengan situasi luar tubuh dapat seimbang.

\section{Ujjayi Pranayama}

Setelah melakukan pranayama ini maka efek lembut pada jaringan syaraf akan terasa. Efek lembut ini akan membuat fikiran menjadi tenang, selain itu pranayama ini juga memiliki efek halus pada bidang batiniah dan dilakukan didalam banyak mudra, serta dalam berbagai teknik meditasi. Pranayama ini dapat dilakukan dengan cara :

Duduklah dengan sikap padmasana atau siddhasana. Mulut ditutup rapat kemudian Tarik nafas pelan - pelan melalui kedua lubang hidung secara halus dan rata hingga nafas mengisi rongga kerongkongan sampai jantung kemudian tahan nafas semampu yang anda dapat lakukan dengan rasa nyaman lalu hembuskan nafas pelan - pelan melalui lubang hidung kiri dengan menutup lubang hidung kanan dengan ibu jari kanan. Busungkan dada saat anda menarik nafas, selama pernafasan akan dihasilkan bunyi khusus akibat penutupan sebagian dari celah suara. Selama melakukan penarikan nafas, bunyi yang dihasilkan harus dalam batas ringan dan seragam. Latihan kumbhaka bahkan boleh dilatih saat berjalan jalan atau berdiri. Sebagai pengganti pengeluaran nafas melalui lubang hidung kiri, anda dapat mengeluarkan nafas pelan - pelan melalui kedua lubang hidung. Efek dari pranayama ini akan melenyapkan panas pada kepala, para praktisi akan menjadi sangat rupawan. Api pencernaan dalam perut akan ditingkatkan. Selain itu latihan ini akan melenyapkan segala kejahatan yang timbul dalam tubuh dan dhatu serta menyembuhkan jalodara (penyakit buang air dalam perut atau ascites). Ia menghilangkan lendir dalam tenggorokan, asma, penyakit TBC dan semua jenis penyakit paru- 
paru dapat disembuhkan. Semua penyakit yang berasal dari kurangnya penarikan zat asam (kurang oksigen dalam pernafasan), dan memperlambat denyut jantung sehingga saat bermanfaat bagi penderita tekanan darah tinggi serta dapat menyembuhkan penyakit jantung. Para praktisi yoga yang tekun melaksanakan pranayama ini tidak akan pernah diserang penyakit karena lendir, urat syaraf, dyspepsia (pencernaan makanan tidak baik), disentri, limpa membesar, TBC, batuk atau demam.dengan melakukan ujjayi pranayama maka kemerosotan badan dan kematian akan dapat dihancurkan. Pranayama ini membuat ketenangan pikiran, hati dan batin dalam tubuh. Penarikan dan penghembusan yang halus dapat membuat seluruh enrgi menjadi singkron dan secara perlahan energi vital dapat dibangkitkan serta ditingkatkan. Ketika energi disentuh secara perlahan melalui pranayama yang lembut ini, enrgi vitalpun akan semakin bangkit dan menyebar keseluruh tubuh, maka dari itu banyak manfaat yang baik melakukan pranayama ini terutama pada bidang kesehatan . Pranayama yang sangat sederhana ini bisa dilakukan banyak orang dimanapun berada, kapanpun dan sedang melakukan apapun, jadi pranayama ini sangat efektif bagi masyarakat yang hidup dimasa kini atau di jaman modern yang memiliki segala aktifitas maupun kesibukan yang luar biasa.

\section{Sitkari Pranayama}

Pranayama ini sangat mirip dengan siali pranayama namun yang membedakan hanya pada posisi lidah. Pranayama ini dilakuakan dengan cara :

Lipatlah lidah sehingga ujung lidah dapat menyentuh langit - langit atas dan hirup udara melalui mulut dengan suara desisan C C C C ( si, si, si). Kemudian tahan nafas semampu yang anda dapat lakukan tanpa merasa terlalu dipaksa, setelah itu hembuskan nafas perlahan melalui kedua lubang hidung. Anda sebaiknya menjaga kedua baris gigi anda saling berhubungan dan kemudian hirup nafas melalui mulut seperti sebelumnya.

Dengan melakukan pranayama ini akan menambah kecantikan (kerupawanan) dan kekuatan tubuh. Latihan ini dapat menghilangkan rasa lapar, haus, malas dan rasa ngantuk. Kekuatannya akn seperti deva indra. Ia dapat mengerjakan dan melepaskan apapun. Ia menjadi penguasa para yogi, mandiri dan tak dapat dilihat. Tidak ada kerugian yang dapat mempengaruhinya. Bila and ahaus lakukan sitkari ini makan dengan segera haus anda akan diredakan. Pranayama ini merupakan alternative terbaik terutamanya ketika melakukan tapa brata puasa, bahkan walaupun tidak melakukan tapa brata puasa pranayama ini bisa dilakukan oleh semua orang dalam keadaan apapun. Pembangkitan energi vital melalui pranayama ini yaitu melalui katupan gigi yang secara perlahan mengolah prana didalam mulut dan menyebarkannya ke seluruh tubuh. Tidak sulit melakukan pranayama ini dimanapun berada.

\section{Sitali Pranayama}

Pranayama ini dilakukan dengan cara menjulurkan lidah sedikit keluar dari mulut, kemudian lipat lidah seperti pipa dan hirup udara melalui mulut dengan desisan suara Si. Tahan nafas semampu anda dengan perasaan nyaman. lalu hembuskan nafas pelan - pelan melaluikedua lubang hidung. Lakukanlah pranayama inis etiap hari secara terus meneus dipagi hari dari 15 menit sampai 30 menit. Anda dapat melakukannya dengan sikap padmasana atau siddhasana, vajrasana, bahkan saat anda berjalan atau berdiri.

Pranayama ini membersihkn darah, meredakan rasa haus dan rasa lapar. Ia juga mendinginkan tubuh, melenyapkan gulma (gangguan pencernaan kronis), dan peradangan 
berbagai jenis penyakit kronis lainnya, demam $\mathrm{TBC}$, pencernaan, gangguan air, empedu, lendir, pengaruh buruk dari racun, digigit ular dsb. Bila anda tersesat dihutan atau dimana saja anda tidak mendapatkan air, bila anda merasa haus, lakukan pranayama ini maka rasa haus anda segera diredakan. Mereka yang melatih pranayama ini dengan teratur, tidak akan terpengaruh oleh gigitan ular atau kalajengking. Sitali kumbaka Adalah tiruan pernafasan dari seekor ular. Para praktisi memperoleh daya pelepasan kulitnya dan ketahanan terhadap kekurangan air, udara, dan makanan. Ia akan menjadi taha akan semua jenis penyakit demam dan panas. Selain itu akan mendorong prana yang bebas diseluruh tubuh. Sama seperti halnya Sitkari Pranayama, Sitali Pranayama juga memberikan pembangkitan energi vital bagi tubuh melalui gerak lidah yang mengambil nafas dan mengolahnya di bagian mulut serta menyebarkannya keseluruh tubuh. Manfaat yang mendalam terutama pengolahan energi vital yang baik sangat didapatkan ketika mempratekkan Sitali Pranayama ini. Bagi masyarakat yang hidup di masa kini yaitu di era modern sangatlah mudah melakukan pranayama ini, bahkan dimanapun dan kapanpun bisa dilakukan teknik ini, karena tidak membutuhkan pakem pakem yang begitu banyak mengikat ketika melakukan pranayama ini.

\section{Bhastrika Pranayama}

Dalam Bahasa sansekerta, bhastrika berarti "hembusan". Pergantian yang cepat dari pengeluaran nafas yang dipaksakan merupakan suatu gambaran dari karakteristik dari bhastrika. Ibarat tiupan alat puput tukang besi hebusannya sangat cepat, demikian juga hendaknya anda menggerakkan nafas anda dengan cepat.

Duduklah dalam sikap padmasana dsn jaga agar badan, leher dan kepala tetap tegak.. tutuplah mulut anda. Selanjutlah Tarik dan keluarkan nafas dengan cepat sebnayak 10 kali seperti tiuapan puput tukang besi. Kerutkan dan kembungkan secara terus menerus. Saat anda melatih pranayama ini akan disertai dengan munculnya suara mendesis. Orang yang mempraktekannya harus memulainya dengan penghembusan nafas secara cepat yang diikuti dengan pergantian yang cepat pula. Bila jumlah hembusan nafas keluar yang diperlukan, sebut saja 10 kali dalam akhir satu putaran. Maka hembusan nafas terakhir diikuti dengan penghirupan nafas sedalam mungkin. Lalu nafas ditahan selama yang mampu dilakukan dengan rasa nyaman. Lalu penghembusan nafas sedalam mungkin dilakukan dengan sangat perlahan. Akhir dari penghebusan nafas dalam ini merupakan akhir dari satu putaran bhastrika. Istirahat sejenak setelah selesai satu putaran setelah mengambil nafas normal. Hal ini akan melegakan dan membuat anda segar kembali untuk memulai putaran kedua. Anda dapat melakukan tiga putaran di malam hari. Orang - orang sibuk yang kesulitan melakukan 3 putaran setiap hari dapat melakukannya minimal satu putaran dengan latihan ini akan dapat membuat mereka tetap segar. Bhastrika merupakan latihan yang sangat kuat yang merupakan kombinasi antara kapalabhati dan ujjayi. Sebelum mulai dengan gerakan bhastrika terlebih dahulu mulailah dengan berlatih kapalabhati dan ujjayi. Maka anda akan mulai melakukan bhastrika.

\section{BAB III KESIMPULAN}

Prānāyāma menempati posisi vital dalam yoga disamping asana. Setiap brahmacari dan grhastha harus melakukannya sebanyak tiga kali setiap pagi, siang dan malam, serta setiap kali melakukan puja dan tri sandhyā. Prānāyāma diharapkan dilakukan dalam setiap aktivitas baik keagamaan maupun dalam aktivitas seharihariPranayama menjadi suatu latihan yang sangat efektif untuk meningkatkan energy vital dalam tubuh terutama pada era modern saat ini ketika gaya hidup manusia sudah tidak lagi sama seperti 
jaman dahulu. Latihan pranayama dengan teratur dan serius dapat memberikan efek yang luar biasa bagi tubuh, bahkan ketika energy vital telah meningkat akibat pranayama ini, maka tubuh lebih disiplin dalam melakukan berbagai hal dalam kehidupan sehari - hari.

\section{DAFTAR PUSTAKA}

Prakash Saraswati. 1996. Patanjali Raja Yoga. Surabaya: Paramita

Iyengar, B.K.S.1985. Light On Pranayama. USA: The Crossroad Publishing Company. Sivananda. 1998. Pengetahuan dan pengendalian prana (Pranayama).Surabaya : Paramita

Sarasvati, Svami Satyananda. 2002.

Asana, Pranayama, Mudra, Bandha.

Surabaya: Paramita

https://gmpjconsulting.com/2014/08/05/ menyeim bangkan-energi-tubuh-cara-mudah-dan- murah-untuksehat-dan-hidup-lebih-produktif/Diakses

tanggal 25 Maret 2019. 